Articles

Studia Iuridica Lublinensia vol. XXVIII, 3, 2019

DOI: 10.17951/sil.2019.28.3.101-116

\author{
Renata Świrgoń-Skok \\ University of Rzeszów \\ ORCID: 0000-0003-2635-6462 \\ rskok@univ.rzeszow.pl
}

\title{
The Impact of Wars on Roman Legislation Regarding vicesima hereditatis and caducum
}

\author{
Wpływ wojen na rzymskie ustawodawstwo odnośnie do vicesima \\ heredistatis i caducum
}

\section{SUMMARY}

The article refers to matters related to vicesima hereditatis and caducum, by means of which a Roman legislator sought financial resources for waging wars. The territorial expansion of Rome, the wars waged, and, in particular, the need to raise funds for their financing affected not only the norms of public law but also individual regulations of Roman private law, including those considering both tax and inheritance law.

Keywords: vicesima hereditatis; caducum; Roman law

I.

Wars have accompanied the Romans since the beginning of statehood. During the Roman Kingdom period, fighting was rather rare and local. This situation changed after the introduction of the republic. This was the beginning of the expansive policy of the Romans, which lasted throughout the times of the Empire. At that time, a great number of wars were being waged, at the same time internal riots took place, causing confusion in the structure of the Roman state.

At the same time, factors facilitating control over the whole country and leading fights started to appear. The road system was extended, military bases were built for future military expeditions and they became fortresses, colonies, beginnings of the Italian cities and provinces. Also, in the sphere of legislation, many legal acts were issued regulating specific matters, and not only those in the field of public but also private law. Among other things, in the preserved source material referring 
to the law of inheritance, one can find regulations, the emergence of which was connected with ongoing fights, or rather with seeking financial resources needed for conducting military expeditions.

In this study, the author presented how the territorial expansion of Rome, the wars, and especially the need to raise funds for the financing of wars influenced individual regulations of Roman private law, concerning both tax and inheritance law. The subject of the article concerns matters related to vicesima hereditatis and caducum, by means of which the Roman legislator sought funds for waging wars. In this way, the Roman state, beginning with Octavian Augustus, gained participation in inheritance after each person, either through a tax of heirs or directly through the acceptance of inheritance.

\section{II.}

The impact of military operations can be particularly noticeable in terms of the Roman tax and inheritance system, which were intended to raise funds for ongoing wars. In ancient Rome, the idea of taxing inheritance appeared relatively late, because it occurred during the times of the republic. Most probably, it was first introduced by the edict of Octavian and Antonius from 40 B.C.:

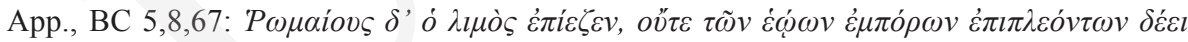

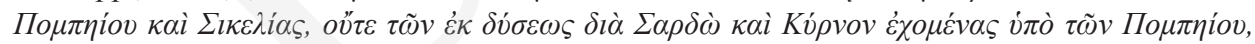

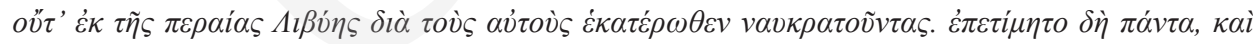

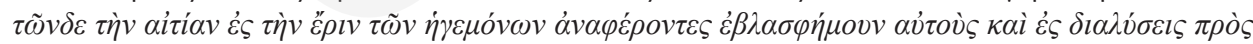
Понтиं

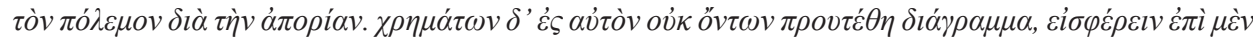

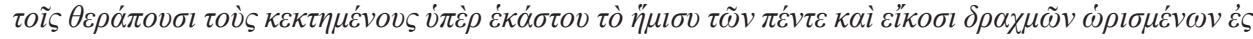

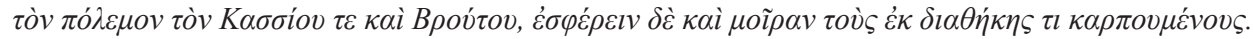

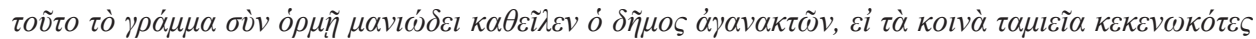

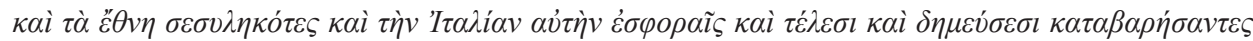

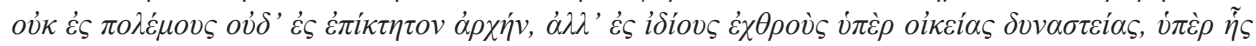

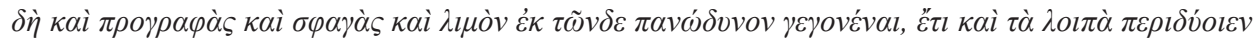

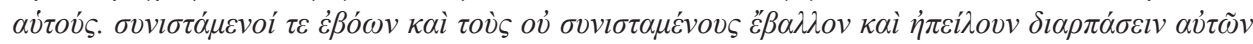

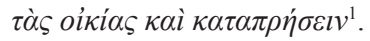

According to the message of Appian of Alexandria ${ }^{2}$, the obligation to pay tax as part of what has been granted in the will, i.e. inheritance due to testamentary suc-

1 Appian. The Civil Wars, ed. L. Mendelssohn, Leipzig 1879.

2 Translations of Appian's works into modern languages: Appian z Aleksandrii, Historia rzymska, t. 2, przeł. L. Piotrowicz, Warszawa 1957; Appien, Histoire romaine livre VII. Le livre la Hannibal, texte établi et traduit par D. Gaillard, Paris 1998; Appien, Histoire romaine livre XI. Le livre syriaque, texte établi et traduit par P. Goukowsky, Paris 2007; Appian z Aleksandrii, Historia 
cession and testamentary legacy. Presumably, it was a way being used by Octavian and Antony to obtain funds for the ongoing civil war with Brutus and Cassius. This one-off tax was probably supposed to serve the end of the Perusine war, but the exact date of its introduction raises some disputes in the literature ${ }^{3}$, although the context of its adoption in reference to wars is seemingly up-to-date. Additionally, the introduction of taxation of inheritance and legate performed by Octavian and Antony in 40 B.C., was supposed to obtain funds for wars by utilizing the increasing significance of testamentary inheritance. It is also the case that in the same year Lex Falcidia ${ }^{4}$ was enacted, encouraging heirs to testaments to accept inheritances even overly burdened with legacy. Therefore, it seems logical, that the imposition of tax over inheritances and legacy would bring measurable funds to the treasury. Also, social dissatisfaction described by Appian was a vivid reaction of the Roman society to the fact that the state started reaching for inheritance property. It seems that until the end of the republic, the inheritance tax was an exceptional solution, occurring sporadically due to financial needs related to waging wars.

The idea of taxing the inheritance, however, returned several decades later, when the consulate of Emilio Lepidus and Lucius Arruntius allowed Octavian August to effectively impose tax on inheritance and legacies (vicesima hereditatum) ${ }^{5}$. The tax

rzymska. Księgi I-XII, przeł. L. Piotrowicz, Wrocław 1957; Appian z Aleksandrii, Historia rzymska, przeł. L. Piotrowicz, t. 1-3, Wrocław 2004.

3 For more details, see A. Ziółkowski, Historia powszechna. Starożytność, Warszawa 2012, p. 7.

4 In terms of the plebeian assembly of 40 B.C., see H. Ankum, La femme mariée et la loi Falcidia, « Labeo » 1984, vol. 30, p. 28 ff.; F. Bonifacio, In tema di lex Falcidia, "IURA" 1952, t. 3, p. 229 ff.; G. Franciosi, Lex Falcidia, SC Pegasianum e disposizioni a scopo di culto, [in:] Studi Donatuti, t. 1, Milano 1973, p. 401 ff.; V. Mannino, Cervidio Scevola e l'applicazione della Falcidia ai legati fra loro connessi, "BIDR” 1981, t. 84, p. 125 ff.; P. De La Rosa Diaz, Algunos aspectos de la lex Falcidia, [in:] Estudios en homenaje al Prof. F. Hernandez-Tejero, t. 2, Madrid 1994, p. 111 ff.; P. Stein, Lex Falcidia, „Ateneum” 1987, Vol. 65, p. 453 ff.; F. Schwarz, Die Rechtswirkungen der lex Falcidia, „ZSS“ 1943, Bd. 63(1), DOI: https://doi.org/10.7767/zrgra.1943.63.1.314, p. 314 ff.; idem, War die lex Falcidia eine lex perfecta, „SDHI“ 1951, Bd. 17, p. 225 and next; A. Wacke, Die Rechtswirkungen der lex Falcidia, [in:] Studien Kaser, Berlin 1973, p. 209 ff.; U. Wesel, Über den Zusammenhang der lex Furia, Voconia und Falcidia, „ZSS“ 1964, Bd. 81(1), DOI: https://doi. org/10.7767/zrgra.1964.81.1.308, p. $308 \mathrm{ff}$.

5 The matter of inheritance and legate tax the following ones wrote: R. Cagnat, Vicesima hereditatium, [in:] Dictionnaire des antiquités grecques et romaines, éd. Ch. Daremberg, E. Saglio (DS), vol. 5, p. 826 ff.; J. Klinkowski, Nowotestamentalny obraz celników na tle systemu finansowego Judei i imperium rzymskiego, „Legnickie Studia Teologiczno-Historyczne” 2007, nr 2, p. 59; M. Kuryłowicz, Vicesima hereditatum. Z historii podatku od spadków, [in:] W kręgu prawa podatkowego i finansów publicznych. Księga dedykowana Prof. C. Kosikowskiemu w 40-lecie pracy naukowej, red. H. Dzwonkowski, Lublin 2005, p. 217 ff.; R. Świrgoń-Skok, Organizacja stużb skarbowych w sprawach podatku od spadków w państwie rzymskim, „Studia Prawnoustrojowe” 2010, nr 12, pp. 243-253; G. Rotondi, Leges publicae populi Romani. Elenco cronologico con una introduzione sull'attivita legislativa dei comizi romani, Milano 1912; G.I. Luzzato, Vicesima hereditatum et manumissionum, [in:] Novissimo Digesto Italiano, t. 20, Torino 1975, p. 809 ff.; L. Rodriguez Alvarez, Notas en torno a la lex Julia de 
was imposed by August on Roman citizens as part of equalizing fiscal obligations between Roman citizens and residents of the province in 6 A.D. through lex Julia de vicesima hereditatum ${ }^{6}$. August, establishing the inheritance tax, probably used an already existing model, which was the inheritance tax paid in Ptolomean Egypt, as well as the Roman tax on the liberation (vicesima libertatis) ${ }^{7}$ and customs (portorium $)^{8}$. In addition, he claimed that the introduction of such tax was the idea of Julius Caesar expressed in his memoirs:

D. 1,2,2,44 (Pomponius libro S. enchiridii): [...] is fuit caesari familiarissimus et libros de iure civili plurimos et qui omnem partem operis fundarent reliquit. nam de legibus vicensimae primus conscribit $[\ldots]$.

In the first volume of the Justinian Digest, compilers put a fragment of Pomponius, who describing the jurist Aulus Ofilius, wrote that being a friend of Julius Caesar, he left numerous law books and he first wrote about the five-percent tax law. This fragment may indicate that Julius Caesar not only planned to introduce such tax, inheritance tax indeed existed in his times. It is difficult to assume that Aulus Ofilius was the first to write about vicesimae manumision, as such a five-percent

vicesima hereditatium, https://dialnet.unirioja.es/descarga/articulo/2035536.pdf [access: 10.10.2019]; G. Wesener, Vicesima hereditatium, [in:] Realencyclopädie der classischen Allerlumswissenschaft, Bd. 8A, Stuttgart 1958, p. 2471 ff.; M. Vigié, Etudes sur les impots indirects. Vicesima libertatis. Vicesima hereditatis, Paris 1883; Ch. Poisnel, Recherches sur l'abolition de la vicesima hereditatum, « Mélanges d'archéologie et d'histoire» 1883, vol. 3, DOI: https://doi.org/10.3406/mefr.1883.6445, pp. 312-327; K.R. Bradley, The vicesima hereditas. Its History and Significance, "Klio" 1984, Vol. 66(66), DOI: https://doi.org/10.1524/klio.1984.66.66.175, pp. 175-182; S. Günther, Die Einführung der römischen Erbschaftssteuer (vicesima hereditatum), „Münstersche Beiträge zur Antiken Handelsgeschichte" 2005, Bd. 24(1), pp. 1-30.

6 The text of this act has not survived to modern times, only the Marcers' comments on it have been preserved (D. 2,15,13; D. 11,7,37; D. 28,1,7; D. 35,2,68; D. 50,16,154) and G. 3,125, PS. 4,6,3, Plin. Paneg. 37, Cass. Dio 60,25, Cass. Dio 72,9. See also W. Litewski, Stownik encyklopedyczny prawa rzymskiego, Kraków 1998, p. 156; Prawo rzymskie. Słownik encyklopedyczny, red. W. Wołodkiewicz, Warszawa 1986, p. 93.

7 In terms of the origin of this tax see M. Kuryłowicz, op. cit., p. 221; G.I. Luzzato, op. cit., p. 811; G. Wesener, op. cit., p. 2472. Analogy to the Roman vicesima hereditatum can be seen in the inheritance tax paid in Ptolomean Egypt. See C. Kunderewicz, Historyczny rozwój odpowiedzialności urzędników w ptolomejskim, rzymskim i bizantyjskim Egipcie, [in:] Studia z rzymskiego prawa administracyjnego, Łódź 1991, p. 15 ff.; S. LeRoy Wallace, Taxation in Egypt from Augustus to Diocletian, New York 1969, p. 234.

8 About portorium see A. Pikulska-Radomska, Portorium w Italii epoki republikańskiej, „Studia Historycznoprawne. Prawo” 2008, t. 305, pp. 263-270; eadem, Uwagi o rzymskim fiskalizmie epoki wczesnego cesarstwa, „Studia Iuridica Toruniensia” 2012, t. 10, DOI: http://dx.doi.org/10.12775/ SIT.2012.002, pp. 37-49; eadem, Fiscus non erubescit. O niektórych italskich podatkach rzymskiego pryncypatu, Łódź 2013; B. Sitek, O finansach prowincjonalnych. Studia nad finansami publicznymi municypium Irni. Kontrola i odpowiedzialność za zarzadzanie środkami publicznymi, „Studia Historycznoprawne. Prawo" 2008, t. 305, pp. 359-368. 
tax on liberation existed since 357 B.C. On the other hand, no sources that would indicate the existence of inheritance tax during that period have survived. It seems that there is a mistake in the text, instead of de legibus vicensimae primus conscribit, it should be de legibus XX libros conscribit ${ }^{9}$. The comments of Aulus Ofilius on the statutes were part of Caesar's codification plan, including inheritance tax ${ }^{10}$.

On the other hand, the position of the princeps guaranteed Octavian Augustus the implementation of the idea regarding the introduction of inheritance and legacies tax, and it ensured the sustainability of income-generating regulations for the state treasury. Admittedly, in 13 A.D., another political solstice took place in Rome and senators wanted to abolish inheritance tax. According to Cassius Dio, senators preferred to pay any tax other than $5 \%$ on inheritance:

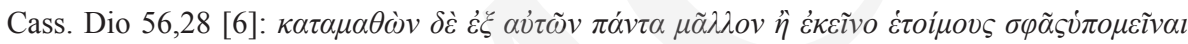

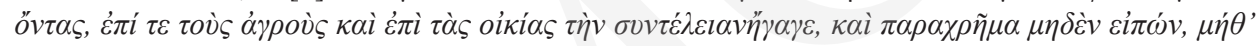

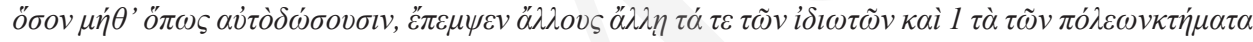

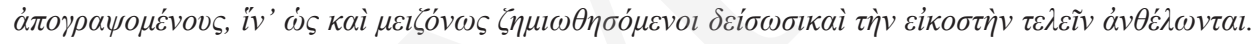
ô $\kappa \alpha i ̀ ~ \varepsilon ́ \gamma \varepsilon ́ v \varepsilon \tau o^{11}$.

However, they resigned from the fight when August threatened to introduce property tax (tributum) for Roman citizens and sent officials to list senator property and land property. For this reason, senators agreed to maintain the inheritance tax.

The proceeds obtained from the inheritance and registration tax from Augustus were allocated to the aeritarium militare ${ }^{12}$, i.e. a special treasure intended for the needs of the army. This special fund for the financing of veterans, in addition to the initial contribution of 70 million sesters from the estate of Augustus ${ }^{13}$, was to be covered by the proceeds from two new taxes in the future, i.e. on public sales of $1 \%$

${ }^{9}$ G. Blicharz, Udziat państwa w spadku. Rzymska myśl prawna w perspektywie prawnoporównawczej, Kraków 2016, p. 44 ff.

${ }^{10}$ E. Polay, Der Kodifizierungsplan des Julius Caesar, „IURA“1965, Bd. 16, p. 48.

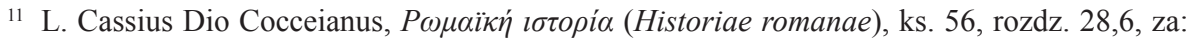
Dio's Roman History. Cassius Dio Cocceianus, eds. E. Cary, H.B. Foster, Vol. 7, London-New York 1955, p. 64.

12 About the aerarium militare established by August in 6 A.D. see Res Geste Divi Augusti 17; M. Cary, H. Scullard, Dzieje Rzymu, Warszawa 1992, p. 59; A. Ziółkowski, Historia Rzymu, Poznań 2004, p. 386 ff. (according to the author, this treasury was created in 5 A.D.); I. Żeber, O pojęciu skarbu państwa w starożytnym Rzymie, [in:] Z dziejów skarbowości, Wrocław 2009, p. 111; M. Corbier, L'aerarium saturni et l'aerarium militare. Administration et prosopographie sénatoriale, Rome 1974; R. Delmaire, Largesses sacrées et res privata. L'aerarium impérial et son administration du IVe au VIe siècle, Rome 1989; P. Fernández Uriel, El Aerarium Militare, "Espacio, Tiempo y Forma. Serie II, Historia Antigua" 2003, núm. 16, DOI: https://doi.org/10.5944/etfii.16.2003.4416, pp. 197-213; The Impact of the Roman Army (200 B.C. - A.D. 476). Economic, Social, Political, Religious and Cultural Aspects, eds. L. de Blois, E. Lo Cascio, Vol. 6, Boston 2007.

${ }^{13}$ Res Geste Divi Augusti 17. 
of the value of items sold (centesima rerum venalium) and inheritance tax (vicesima hereditatum). This treasury was entrusted to the management of praefecti aerarii militaris, who were often elected from the group of former praerores aerarii ${ }^{14}$.

The introduction of inheritance tax always required justification and was a solution that caused political conflict. Earlier Republican taxes were one-off and were treated as loans granted by citizens of the state. As a rule, Roman citizens were free from taxes and their imposition was treated as a violation of their position. However, with the emergence of the Empire, fixed taxes for citizens appeared, including inheritance tax. Moreover, it was supposed to execute no matter where the Romans were at each particular moment. During the imperial period, the effectiveness and usefulness of a given legal solution for the state became more important. Perhaps due to the growing costs of maintaining imperium, it was the most equitable instrument ensuring stable income to the military treasury.

A detailed analysis of the inheritance tax is difficult due to the fact that in Justinian times, the tax did not exist and only a small number of sources related to this matter were included in the Justinian codification ${ }^{15}$. In particular, Pliny the Younger mentions inheritance tax in Panegyricus (fragments 37-40) ${ }^{16}$.

Plin. Paneg. 37: His Vicesima reperta est, tributum tolerabile et facile heredibus dumtaxat extraneis, domesticis grave.

Thus, the inheritance tax was one-twentieth (or 5\%) of the value of assets inherited or received through a legate. In addition, the lex Julia de vicesima hereditatum did not provide for a tax-free amount, but the decrease in its insignificant value was excluded from its operation:

Plin. Paneg. 40: Carebit onere vicesimae parva et exilis hereditas: et si ita gratus heres volet, tota sepulcro, tota funeri serviet. Nemo observator, nemo castigator adsistet. Cuicumque modica pecunia ex hereditate alicuius obvenerit, securus habeat quietusque possideat. Ea lex Vicesimae dicta est, ut ad periculum eius perveniri, nisi opibus, non posit.

${ }^{14}$ See Svetonius, Augustus, 36; Tacitus, Annales, 13,29; R.S. Rogers, The Roman Emptores as Heirs and Legatees, "Transactions and Proceedings of the American Philological Association" 1947, Vol. 78, DOI: https://doi.org/10.2307/283490, pp. 140-158.

15 The place of the vicesima hereditatum was probably taken from the time of Diocletian's property tax. See Suetonius de Caesaribus 39,31.

16 Vicesima hereditatum is also mentioned in the following source fragments D. 1,2,2,44 (Pomponius); Gaius' Institutions (Gai. 3,125); The Justinian Codex (C.6,3,33 z 531); Paulus' Sentences (PS. 4,6,1; 4,6,3). Additionally, vicesima hereditatum is also mentioned in non-judicial sources, such as: Cassius Dio $(55,25)$ and Livius $(41,29,54)$. 
According to Pliny, inheritance tax and low-value legates, probably less than 100,000 sesters, were not covered by the inheritance tax ${ }^{17}$. In addition, inheritances from close relatives were free from vicesima hereditatum. The Act did not specify precisely what degree of kinship is being mentioned:

Plin. Paneg. 38: Statim ergo muneri eius liberalitas tua adstruxit, ut, quemadmodum in patris filius, sic in hereditate filii pater esset immunis, nec eodem momento, quo pater esse desisset, hoc quoque amitteret, quod fuisset.

Plin. Paneg. 39: Nec vero contentus primum cognationis gradum abstulisse Vicesimae, secundum quoque exemit, cavitque, ut in sororis bonis frater, et contra, in fratris soror, utque avus, avia, in neptis nepotisque, et invicem illi, servarentur immunes.

In the first passage, Pliny mentions inheritance between parents and children, but it seems that this is not a precise term. In the next passage, he adds that inheritance tax was limited not only to the first degree of kinship but also second-degree relatives, i.e. brother, sister, grandfather and grandmother as well as grandchild and grandson, were excluded from the vicesima hereditatum. The closest cognitive relatives (so-called decem personae) were probably released from the obligation to pay vicesima hereditatum ${ }^{18}$.

Initially, this tax was charged only to Roman citizens living in Rome as well as in Italy and the provinces. In the Principate period, the scope of entities obliged to pay vicesima hereditatum was broadened as a result of obtaining Roman citizenship by new groups of Empire residents. Additionally, these exemptions did not apply to kinship, since the calculation of kinship degrees was only applied to former Roman citizens:

Plin. Paneg. 37: Haec mansuetudo legis veteribus civibus servabatur: novi, seu per Latium in civitatem, seu beneficio principis venissent, nisi simul cognationis iura impetrassent, alienissimi habebantur, quibus coniunctissimi fuerant.

Those who were granted Roman citizenship by way of Emperor's privileges could benefit from kinship reprieves only during the times of the emperor Nerva and Trajan, with subsequent emperors revoking the privileges granted to new citizens:

17 This amount is mostly provided in literature. There are also opinions that the amount was 200,000 sesters (A. Berger, Encyclopedic Dictionary of Roman Law, Philadelphia 1953, p. 764). Plinius writes that a small and insignificant amount of the inheritance was excluded. For more details, see M. Kuryłowicz, op. cit., p. 219.

${ }_{18}$ Compare also I. 3,9,3: [...] decem personis quas extraneo manumissori praeferebat (sunt autem decem personae hae: pater, mater, avus, avia, tam paterni quam materni, item filius, filia, nepos, neptis, tam ex filio quam ex filia, frater, soror, sive consanguinei sive uterini); Coll. 16,9,3; G.I. Luzzato, op. cit., p. 809; M. Kuryłowicz, op. cit., p. 218; G. Wesener, op. cit., p. 2472. 
Plin. Paneg. 39: His quoque, quibus per Latium civitas Romana patuisset, idem indulsit, omnibusque inter se cognationum iura commisit, simul et pariter, et more naturae; quae priores principes a singulis rogari gestiebant, non tam praestandi animo, quam negandi.

For the occurrence of this tax, it did not matter whether the inheritance (the legate) was acquired by way of testamentary inheritance or non-testamentary inheritance. With legates that were encumbered with vicesima hereditatum, regardless of the inheritance, the testator sometimes pointed out that the entry was included with or without tax. Probably every heir (co-heir) and each employee paid the tax separately. The fact that the heir also deducted the costs of the funeral and the average tombstone (et si ita gratus heres volet, tota sepulcro, tota funeri serviet) from the value of the estate, which indirectly could influence the amount of legates, also taking into account the Falcidia quarrel ${ }^{19}$.

In addition, Hadrian accelerated the payment of vicesima hereditatum, because the rules for opening a will were changed, which was performed in a relevant tax office (statio vicesimae):

Pauli Sent. 3,5,14: Sive falsum sive ruptum sive irritum dicatur esse testamentum, salva eorum disceptatione scriptus heres iure in possessionem mitti desiderat.

Pauli Sent. 3,5,18: In possessionem earum rerum, quas mortis tempore testator non possedit, heres scriptus, priusquam iure ordinario experiatur, improbe mitti desiderat.

In addition, by virtue of edict of Hadrian to accelerate the payment of inheritance tax, the heir was brought into possession of inheritance property (in possessionem mitti) if the will was valid, even if it was later questioned in the intestate succession proceeding ${ }^{20}$. Hadrian considers inheritance tax as a useful instrument to ensure stable and high inflows to the State Treasury. Therefore, the person constituted as an heir could have acquired possessio after the payment of the tax.

Moreover, the claim for the payment of vicesima hereditatum was treated as privileged:

Pauli Sent. 5,12,10: Privilegium fisci est inter omnes creditores primum locum retinere.

Paulus states that the fiscus enjoys a privilege (privilegium fisci), under which its claims have priority in enforcement proceedings before other creditors ${ }^{21}$.

19 See Plin. Paneg. 40. Cf. D. 11,7,37 pr. - 1 Macer.; M. Kuryłowicz, op. cit., p. 219; R. Świrgoń-Skok, op. cit., pp. 243-253; G. Wesener, op. cit., p. 2475.

20 This provision was abolished by Justinian in C. 6,33,3.

${ }^{21}$ Por. M. Kaser, Das Römische Privatrecht, Bd. 1, München 1971, p. 734. 
Emperor Caracalla raised the amount of inheritance tax and legates up to $10 \%$ of the value of inherited property, additionally, by issuing Constitutio Antoniniana in 212 A.D., he granted all free citizens of the Empire Roman citizenship and increased the scope of entities burdened with vicesima hereditatum ${ }^{22}$. This emperor is known for his efforts to gain new income and changes in the monetary system. In addition, the interest in this tax at the beginning of the crisis, that took place in the Empire in the $3^{\text {rd }}$ century confirms its budgetary usefulness. The tax returns to the previous level $(5 \%)$ and earlier exclusions during the reign of Macrinus ${ }^{23}$.

In Justinian law, the inheritance tax was abolished, while the provisions regarding the opening of wills concerning private wills were retained by Justinian:

\section{6,33,3: Imperator Justinianus: [...] quia et vicesima hereditatis a nostra recessit re publica [...].}

In his constitution, Justinian writes about vicesima hereditatum as an already non-binding tax. Probably this tax was abolished by the emperors Diocletian and Constantine as part of the financial reforms carried out ${ }^{24}$.

III.

The next legal regulation of the Roman inheritance system, but also the tax system in connection with securing the proceeds to the state's estate, among others for the needs of wars, were the provisions regarding the caducum ${ }^{25}$. As I mentioned, during the times of Augustus, there was a change concerning the taxation system of citizens, as taxes began to be collected on a permanent basis, and a special treasure for aerarium militarae was created for the needs of veterans and the army, and the institution of caducum was to increase the revenue to this estate.

The concept of caducum is combined with the person of the first princeps in the doctrine of Roman law. August introduced the institutions in the so-called marriage laws (otherwise lex Iulia et Papia, lex caducaria or lex Iulia caducaria) ${ }^{26}$, i.e. lex Iulia de maritandis oridinibus, in 9 A.D. and lex Papia Poppea in 9 A.D. On the

22 About Constitutio Antoniniana see M. Jaczynowska, Historia starożytnego Rzymu, Warszawa 1986, p. 313; eadem, Dzieje Imperium Romanum, Warszawa 1996, p. 337 ff.

${ }_{23}$ See Plin. Paneg. 38; Coll. 16,9,3; Cass. Dio. 77,9-78,12. Cf. M. Kuryłowicz, op. cit., p. 218; G. Wesener, op. cit., p. 2472.

${ }^{24}$ M. Cary, H. Scullard, op. cit., p. 390 ff.

${ }_{25}$ P. Voci, Diritto ereditario romano, Milano 1960, p. 59; B. Biondi, Successione testamentaria e donazioni, Milano 1943, p. 143; G. Blicharz, op. cit., p. 271 ff.

${ }^{26}$ E. Bund, Erbrechtliche Geldquellen römischer Kaiser, [in:] Festschrift für F. Wieacker zum 70. Geburtstag, Hrsg. O. Behrends, M. Diesselhorst, H. Lange, D. Liebs, J.G. Wolf, Ch. Wollschläger, Göttingen 1978, p. 59 ff. 
grounds of these acts, August introduced restrictions on the acquisition of inheritances by unmarried or childless people, using the concept of capacitas, which means inherence ability. In the preserved source material, the oldest messages referring to the said regulation are texts from the Gaius Institutes:

G. 2,111: Caelibes quoque, qui lege Iulia hereditates legataque capere uetantur, item orbi, id est qui liberos non habent, quos lex [.... fol. deperd., vv. 21 exceptis frustulis paucis legi nequeunt ........].

G. 2,286: Caelibes quoque, qui per legem Iuliam hereditates legataque capere prohibentur, olim fideicommissa videbantur capere posse.

G. 2,286a: Item orbi, qui per legem Papiam ob id, quod liberos non habent, dimidias partes hereditatum legatorumque perdunt, olim solida fideicommissa videbantur capere posse. sed postea senatus consulto Pegasiano proinde fideicommissa quoque ac legata hereditatesque capere posse prohibiti sunt; eaque translata sunt ad eos, qui in eo testamento liberos habent, aut si nulli liberos habebunt, ad populum, sicuti iuris est in legatis et in hereditatibus, quae eadem aut simili ex causa caduca fiunt.

In the first of the analyzed passages, Gaius writes about the caduca when discussing the inheritance abilities of the unmarried and childless in the context of a soldier's will. The next two parts deal with fiduciary records and their comparison with the provisions of civil law. Although Gaius does not use the word aerarium populi romani in the quoted passus (G. 2,266a), he only writes ad populum, the researchers emphasize that the term should be understood as the state treasury, which is then referred to as the fiscus term ${ }^{27}$.

According to the source messages, the inheritance left for unmarried people, who lost their capacitas, on the basis of lex Iulia, was transferred (translata sunt), or other called in the will, who had children or ad populum, unless they married within 100 days. If all those appointed in the will were caelibes, then the inheritance as caducum was received by the legatees who met the requirement of having children. In the event that none of the heirs and legatees meet the requirement of having offspring, then the inheritance is granted to the state treasury. However, punishment for celibacy excluded only a valid marriage iure civili (iustae nuptiae) and one being in accordance with the principles contained in lex Iuliae et Papiae Poppaeae. Equally to marriage, there was engagement (sponsalia), provided that the marriage was concluded within two years. Women were free from penalties for celibacy during vacationis, i.e. according to lex Iulia after the death of the husband for one year, after the dissolution of the marriage for six months, and according to lex Papia in the first case for two years, in the second for one year and six months.

${ }^{27}$ Cf. B. Biondi, op. cit., pp. 145-146. 
The childless (orbi) and women during vacatio, according to lex Papia, had the ability to inherit only half of the inheritance, unless they had received a relevant number of children within 100 days. One child would be enough for a man, while a woman should have at least three of them, and a liberated woman one should have at least four children. Children should result from marriage, from an unbanned marriage lege Iulia et Papia Poppaea. Originally, men were free from punishment for being childless through adoptio, but this resolution was overturned by the senatus consultum Memmianum from the times of Nero. The rest of such an inheritance belonged to the state in accordance with the law of the caducum, unless others appointed in the will did not meet the requirement of having children.

The doctrine connected with the ius caducum has already introduced the categories of inheritances and legates that were ex causa caduca during the time of Augustus. There can be include spouses in a mutual relationship because their capacitas were differently defined. At the time of death of one spouse, the other one became caelebs, but only in relation to the inheritance of a third person, but he was eligible for limited inheritance after the deceased spouse, in particular, a childless spouse could receive a tenth of the total estate of the deceased spouse due to marriage, and had the right to use one-third.

In addition, there was a category of people who were completely excluded from the provisions of the above-mentioned acts for various reasons, as solidi capacitas could acquire entirely what the deceased had left, despite being married or childless. This group of people included, among others, persons due to their age ${ }^{28}$ or physical disability (spadones). In addition, the cognitive relatives to the sixth degree of the deceased, and from the seventh natus vel nata ex sobrino sobrinave, as well as the heir appointed to the insolvent inheritance, because he actually received nothing. For the same reason, anyone who was required to give inheritance to a third party as a fidei-commissum.

The key matter in the analysis of the caducum matter is the decision whether these provisions were applicable only in the testamentary succession, or whether it included a reference to inheritance under the law. The constitution of Justinian from 534 may be helpful here, although the institution itself does not apply in Justinian law:

${ }^{28}$ Because of their age, they were released from punishments for celibacy and childlessness: a man under 25 and over 60, a woman under 20 and over 50. Later, however, Senatus Pernicianum decided that the persons under 60 should be taken out from this act, a woman up to 50 years of age would neither enter into marriage nor have children. This changed Senatus Claudianum because it freed from celibacy for a 60-year-old man who married a woman in his late 50s. On the contrary, a woman over 50 who married a man under 60 years of age did not acquire capacitatem. 
C. 6,51,1,14 (Imperator Justinianus): Haec autem omnia locum habere censemus tam in testamentis sive scriptis sive sine scriptis habitis quam in codicillis et omni ultimo elogio vel si quid ab intestato fuerit derelictum nec non in mortis causa donationibus.

It seems that the provisions referring to the caducum were applicable in both testamentary and non-testamentary inheritance.

An entire system was established - the so-called delatores ${ }^{29}$, meaning informants who, being notified of the caducum, received half of the value of the claimed property as a reward. This was to reduce the administrative costs associated with the enforcement of such inheritances and to increase the effectiveness of the regulation. Of course, such a solution caused great social opposition. For example, Tacitus wrote about it in his Annals:

Tac. Ann. 3,28: Acriora ex eo vincla, inditi custodes et lege Papia Poppaea praemiis inducti ut, si a privilegiis parentum cessaretur, velut parens omnium populus vacantia teneret. sed altius penetrabnat urbemque et Italiam et quod usquam civium corripuerant, multorumque excisi status.

In addition, attempts were made to limit abuse by delatores:

D. 49,14,15,3 (Mauricius): Senatus hadriani temporibus censuit, cum quis se ad aerarium detulerit, quod capere non potuerit, ut totum in aerarium colligatur et ex eo pars dimidia sibi secundum beneficium divi Traiani restituatur.

Emperor Trajan established a privilege for heirs or legatees who did not meet the conditions for the acquisition of the inheritance, so that they could report it themselves and thus keep half of the reported inheritance. This privilege was also confirmed by Hadrian. In addition, as reported by Suetonius, Nero reduced the prize for reporting the caducum to one-fourth of the value of the property. Because from the times of Trajan and Hadrian, more attention was paid to informing about incapacitas instead of the performance of informers ${ }^{30}$. Anyway, delatores regulations became the subject of the imperial constitutions, because they wanted to limit the abuse of informers willing to enrich themselves on someone else's loss.

The law of the caducum, just like the inheritance tax, was abolished by Justinian:

C. 6,51,1 pr. - 1: (Imperator Justinianus): Et nomen et materiam caducorum ex bellis ortam et auctam civilibus, quae in se populus romanus movebat, necessarium duximus, patres conscripti, in pacificis nostri imperii temporibus ab orbe romano recludere, ut, quod belli calamitas introduxit, hoc pacis lenitas sopiret. Et quemadmodum in multis capitulis lex papia ab anterioribus principibus emendata fuit et per desuetudinem abolita, ita et a nobis circa caducorum observationem invidiosum

29 See P. Cerami, Accusatores populares, delatores, indices. Tipologia dei collaboratori di giustizia nell'antica Roma, "Annali Palermo" 1998, n. 45, pp. 119-143.

${ }^{30}$ D. 49,14,13 (Paulus libro septimo ad legem Iuliam et Papiam); Svetonius, Neron, 10: Praemia delatorum Papiae legis ad quartas redegit. 
suum amittat vigorem, qui et ipsis prudentissimis viris displicuit, multas invenientibus vias, per quas caducum ne fieret.

In the analyzed constitution, Justinian clearly indicates that the law of the $c a$ ducum, which appeared in the period of intensified wars, is now pointless in times of peace. He argues that lex Papia has already been changed by earlier emperors and is being repealed by the lack of application. Therefore, the connection between the emergence of regulations concerning the caducum and the wars comes to the fore. The Roman state is more and more interested in taking over the inheritance estate more quickly, when funds for the army and waging wars are needed. According to the discussed constitution, civil wars contributed to the more frequent takeover of inheritances by the state. On the other hand, in the time of Justinian, the issue of financing soldiers was not the most important problem of the Empire, which is why the need for existing regulations regarding the caducum was eliminated. Justinian clearly opposes the republican wars and the caducum to the time of peace and restrictions on the part of the tax office during his time ${ }^{31}$.

Obviously, among the reasons for the enactment of matrimonial laws performed by Augustus (lex Iulia de maritandis oridinibus from 9 A.D. and lex Papia Poppea from 9 A.D.), the incentive to remain in marriage and to have children should be raised in the first place, which was very beneficial to the state economy, but searching for ways to increase treasury revenues cannot be forgotten at the same time. It seems that the basic purpose of these laws were fiscal matters. The limitation of the inheritance capacity meant that the inheritance could be granted to other people appointed in the will, who met the statutory requirements, but it could also become the property of the state, which could have acquired inheritance sooner than ever before in Roman law.

IV.

Briefly summarizing, it can be stated that Octavian Augustus, introducing both the inheritance tax and the institution of the caducum, pursued a broader legal policy in which the state is being called to privileged participation in inheritance. On the one hand, the caducum regime was a strong motivation for getting married and having children, on the other hand, the emperor expected revenues for the state treasury. The revenues that were supposed to supply the aerarium militarae and be used for the needs of veterans and the army, were influenced first of all by the enactment vicesima hereditatis in 6 A.D., and finally the law of the caducum, which was finally settled three years later. This way, the Roman state, beginning

31 C. Tanta of 533 A.D. 
with Octavian Augustus, gained participation in inheritance after each person, either through heirs in the form of tax or directly through the acceptance of inheritance.

In these solutions, one can see the republican approach of the state's participation in the property of its citizens. The state's entitlement to taxes, public levies or inheritance takeovers was allowed only in emergency situations, for a specific purpose, first of all for waging wars.

\section{REFERENCES}

Ankum H., La femme mariée et la loi Falcidia, « Labeo » 1984, vol. 30.

Appian. The Civil Wars, ed. L. Mendelssohn, Leipzig 1879.

Appian z Aleksandrii, Historia rzymska, przeł. L. Piotrowicz, t. 1-3, Wrocław 2004.

Appian z Aleksandrii, Historia rzymska, t. 2, przeł. L. Piotrowicz, Warszawa 1957.

Appian z Aleksandrii, Historia rzymska. Księgi I-XII, przeł. L. Piotrowicz, Wrocław 1957.

Appien, Histoire romaine livre VII. Le livre la Hannibal, texte établi et traduit par D. Gaillard, Paris 1998.

Appien, Histoire romaine livre XI. Le livre syriaque, texte établi et traduit par P. Goukowsky, Paris 2007.

Berger A., Encyclopedic Dictionary of Roman Law, Philadelphia 1953.

Biondi B., Successione testamentaria e donazioni, Milano 1943.

Blicharz G., Udziat państwa w spadku. Rzymska myśl prawna w perspektywie prawnoporównawczej, Kraków 2016.

Bonifacio F., In tema di lex Falcidia, "IURA" 1952, t. 3.

Bradley K.R., The vicesima hereditas. Its History and Significance, "Klio" 1984, Vol. 66(66), DOI: https://doi.org/10.1524/klio.1984.66.66.175.

Bund E., Erbrechtliche Geldquellen römischer Kaiser, [in:] Festschrift für F. Wieacker zum 70. Geburtstag, Hrsg. O. Behrends, M. Diesselhorst, H. Lange, D. Liebs, J.G. Wolf, Ch. Wollschläger, Göttingen 1978.

Cagnat R., Vicesima hereditatium, [in:] Dictionnaire des antiquités grecques et romaines, éd. Ch. Daremberg, E. Saglio (DS), vol. 5.

Cary M., Scullard H., Dzieje Rzymu, Warszawa 1992.

Cerami P., Accusatores populares, delatores, indices. Tipologia dei collaboratori di giustizia nell'antica Roma, "Annali Palermo" 1998, n. 45.

Corbier M., L'aerarium saturni et l'aerarium militare. Administration et prosopographie sénatoriale, Rome 1974.

De La Rosa Diaz P., Algunos aspectos de la lex Falcidia, [in:] Estudios en homenaje al Prof. F. Hernandez-Tejero, t. 2, Madrid 1994.

Delmaire R., Largesses sacrées et res privata. L'aerarium impérial et son administration du IVe au VIe siècle, Rome 1989.

Dio's Roman History. Cassius Dio Cocceianus, eds. E. Cary, H.B. Foster, Vol. 7, London-New York 1955.

Fernández Uriel P., El Aerarium Militare, "Espacio, Tiempo y Forma. Serie II, Historia Antigua” 2003, núm. 16, DOI: https://doi.org/10.5944/etfii.16.2003.4416.

Franciosi G., Lex Falcidia, SC Pegasianum e disposizioni a scopo di culto, [in:] Studi Donatuti, t. 1, Milano 1973.

Günther S., Die Einführung der römischen Erbschaftssteuer (vicesima hereditatum), „Münstersche Beiträge zur Antiken Handelsgeschichte“ 2005, Bd. 24(1).

Jaczynowska M., Dzieje Imperium Romanum, Warszawa 1996. 
Jaczynowska M., Historia starożytnego Rzymu, Warszawa 1986.

Kaser M., Das Römische Privatrecht, Bd. 1, München 1971.

Klinkowski J., Nowotestamentalny obraz celników na tle systemu finansowego Judei i imperium rzymskiego, „Legnickie Studia Teologiczno-Historyczne” 2007, nr 2.

Kunderewicz C., Historyczny rozwój odpowiedzialności urzędników w ptolomejskim, rzymskim i bizantyjskim Egipcie, [in:] Studia z rzymskiego prawa administracyjnego, Łódź 1991.

Kuryłowicz M., Vicesima hereditatum. Z historii podatku od spadków, [in:] W kręgu prawa podatkowego i finansów publicznych. Księga dedykowana Prof. C. Kosikowskiemu w 40-lecie pracy naukowej, red. H. Dzwonkowski, Lublin 2005.

LeRoy Wallace S., Taxation in Egypt from Augustus to Diocletian, New York 1969.

Litewski W., Słownik encyklopedyczny prawa rzymskiego, Kraków 1998.

Luzzato G.I., Vicesima hereditatum et manumissionum, [in:] Novissimo Digesto Italiano, t. 20, Torino 1975.

Mannino V., Cervidio Scevola e l'applicazione della Falcidia ai legati fra loro connessi, "BIDR" 1981, t. 84.

Pikulska-Radomska A., Fiscus non erubescit. O niektórych italskich podatkach rzymskiego pryncypatu, Łódź 2013.

Pikulska-Radomska A., Portorium w Italii epoki republikańskiej, „Studia Historycznoprawne. Prawo” 2008, t. 305.

Pikulska-Radomska A., Uwagi o rzymskim fiskalizmie epoki wczesnego cesarstwa, „Studia Iuridica Toruniensia" 2012, t. 10, DOI: http://dx.doi.org/10.12775/SIT.2012.002.

Poisnel Ch., Recherches sur l'abolition de la vicesima hereditatum, « Mélanges d'archéologie et d'histoire » 1883, vol. 3, DOI: https://doi.org/10.3406/mefr.1883.6445.

Polay E., Der Kodifizierungsplan des Julius Caesar, „IURA“ 1965, Bd. 16.

Prawo rzymskie. Słownik encyklopedyczny, red. W. Wołodkiewicz, Warszawa 1986.

Rodriguez Alvarez L., Notas en torno a la lex Julia de vicesima hereditatium, https://dialnet.unirioja. es/descarga/articulo/2035536.pdf [access: 10.10.2019].

Rogers R.S., The Roman Emptores as Heirs and Legatees, "Transactions and Proceedings of the American Philological Association" 1947, Vol. 78, DOI: https://doi.org/10.2307/283490.

Rotondi G., Leges publicae populi Romani. Elenco cronologico con una introduzione sull'attivita legislativa dei comizi romani, Milano 1912.

Schwarz F., Die Rechtswirkungen der lex Falcidia, „ZSS“ 1943, Bd. 63(1),

DOI: https://doi.org/10.7767/zrgra.1943.63.1.314.

Schwarz F., War die lex Falcidia eine lex perfecta, „SDHI“ 1951, Bd. 17.

Sitek B., O finansach prowincjonalnych. Studia nad finansami publicznymi municypium Irni. Kontrola i odpowiedzialność za zarządzanie środkami publicznymi, „Studia Historycznoprawne. Prawo" 2008, t. 305.

Stein P., Lex Falcidia, „Ateneum” 1987, Vol. 65.

Świrgoń-Skok R., Organizacja służb skarbowych w sprawach podatku od spadków w państwie rzymskim, „Studia Prawnoustrojowe” 2010, nr 12.

The Impact of the Roman Army (200 B.C. - A.D. 476). Economic, Social, Political, Religious and Cultural Aspects, eds. L. de Blois, E. Lo Cascio, Vol. 6, Boston 2007.

Vigié M., Etudes sur les impots indirects. Vicesima libertatis. Vicesima hereditatis, Paris 1883.

Voci P., Diritto ereditario romano, Milano 1960.

Wacke A., Die Rechtswirkungen der lex Falcidia, [in:] Studien Kaser, Berlin 1973.

Wesel U., Über den Zusammenhang der lex Furia, Voconia und Falcidia, „ZSS“ 1964, Bd. 81(1), DOI: https://doi.org/10.7767/zrgra.1964.81.1.308.

Wesener G., Vicesima hereditatium, [in:] Realencyclopädie der classischen Allerlumswissenschaft, Bd. 8A, Stuttgart 1958. 
Pobrane z czasopisma Studia Iuridica Lublinensia http://studiaiuridica.umes.pl Data: 26/04/2023 10:34:35

Ziółkowski A., Historia powszechna. Starożytność, Warszawa 2012.

Ziółkowski A., Historia Rzymu, Poznań 2004.

Żeber I., O pojęciu skarbu państwa w starożytnym Rzymie, [in:] Z dziejów skarbowości, Wrocław 2009.

\section{STRESZCZENIE}

W artykule odniesiono się do zagadnień związanych z vicesima heredistatis i caducum, za pomocą których rzymski prawodawca szukał środków finansowych na prowadzenie wojen. Ekspansja terytorialna Rzymu, prowadzone wojny, a zwłaszcza potrzeba gromadzenia funduszy na ich finansowanie wpływały nie tylko na normy prawa publicznego, lecz także na poszczególne unormowania rzymskiego prawa prywatnego, w tym na te z pogranicza prawa podatkowego i spadkowego.

Słowa kluczowe: vicesima heredistatis; caducum; prawo rzymskie 